\title{
CAPE COD CANAL 1
}

\author{
By Wm. Barclay Parsons, C. E., \\ New York.
}

In the consideration of an inside water route along the Atlantic seaboard of the United States, the link that will connect the waters of Long Island Sound and Massachusetts Bay is, in respect of size and character of vessels and the extent of tonnage that will use it, the most important, and historically the most interesting of all the sections that, when completed, will make possible a voyage from Maine to the Gulf of Mexico free from interference by stress of weather or attack by enemy in case of war.

A glance at the map of Massachusetts shows projecting from its southeastern corner a great arm, running first easterly thirtyfive miles and then northerly about the same distance, terminating in a hook at Provincetown. To this arm the name of Cape Cod is applied. This curious geographical formation is everywhere flat, with few hills, especially to the east, and is composed chiefly of sand and gravel. Around this cape all sea-going traffic between Massachusetts Bay ports, such as Boston and Portland, and all ports lying to the south must pass.

The circumnavigation of the cape is far from easy. On the south side lie Martha's Vineyard and Nantucket Islands, inclosing Vineyard and Nantucket Sounds, with their high tidal currents and many shoals; while to the east are the great shoals extending southeasterly to the celebrated Nantucket shoals, marked by the light vessel of that name. These shoals, the low, sandy coast, difficult to see in thick weather, the frequent fogs, and the unbroken exposure to northeast storms, have made the passage of the cape a dreaded one to all mariners, and the record of wrecks year by year, with their shocking loss of ships, cargoes and life, is ample testimony that their fears do not lack foundation.

The only place on the cape where its breadth is material is the southerly projection towards Falmouth, which, with the extended chain of islands, forms the eastern shore of Buzzards Bay.

'This paper was read before the Atlantic Deeper Waterways Conference, Philadelphia, November $19,1907$. 
At the head of the bay the distance overland to Barnstable Bay is less than eight miles. This distance is made up in chief part by the Monument River, to the south and the Scusset River to the north. Separating them is a ridge whose height is only thirty feet above sea level. The deepening of the rivers and the cutting of a canal through this ridge, making thereby a direct water route, avoiding the journey around the cape, is so obvious a shortening of distance and reduction of marine risks as to cause wonder it was not long since done. The contemplation of such a channel is, in fact, almost coeval with the Pilgrim settlement at Plymouth in I620. The records of that colony show that in 1622 a party succeeded in getting a boat around the cape, only to have it lost in Vineyard Sound. The year following they discovered that from Manomet, an Indian town within twenty miles of Plymouth, there flowed a river southerly to a bay which opened towards Narragansett, and within a short time afterwards the thrifty colonists established there a trading station, between which and the Dutch settlement at Fort Amsterdam there at once developed a brisk trade, the Dutch vessels ascending the river to Manomet, whence the goods were carried the short remaining distance overland to Massachusetts Bay. Before the seventeenth century was one-third gone there was thus established the beginning of the Boston-New York water-borne trade, which has since grown to such huge proportions. The old name of Manomet has unfortunately been corrupted into the meaningless form of Monument, and as such is now applied to the river which the Plymouth colonists found.

The idea of extending this river not over two miles to the north so as to make a continuous waterway and dispense with a land portage must have soon occurred to the traders. At least no later than 1676 one Samuel Sewall records in his diary, under date of October 26th: "Mr. Smith, of Sandwich, rode with me and showed me the place which some had thought to cut, for to make a passage from the south sea to the north."

Officially, however, things moved slowly then, as they do now, and it is not until 1697 , or seventy years after the arrival of the Dutch vessel from New Amsterdam, that the authorities' attention seems to have been drawn to it. In that year the records of October 3oth, of the House of Representatives, contain the following resolution : 
WHEREAS, It is thought by many to be very necessary for the preservation of man and estates, and very profitable and useful to the public, if a passage be cut through the land at Sandwich from Barnstable Bay, so called, into Monament Bay, for vessels to pass to and from the western part of this country,

Ordered, That Mr. Hohn Otis, of Barnstable, Captain William Bassett and Mr. Thomas Smith, of Sandwich, be and are hereby appointed to view the place, and make report to this Court, at their next sessions, what they judge will be the General Conveniences and inconveniences that may accrue thereby, and what the charge of the same may be, and probability of effecting thereof.

So far as the records give evidence, these citizens have not yet reported. In fact, as to any action by the Colony of Massachusetts, the matter lay dormant until May, 1776, when the General Court passed this resolve:

In Council. Whereas, It is represented to this Court that a navigable canal may without much difficulty be cut through the isthmus which separates Buzzards Bay and Barnstable Bay, whereby the Hazardous Navigation round Cape Cod, both on account of the shoals and enemy, may be prevented, and a safe communication between this colony and the southern colonies be so far secured,

Resolved, That James Bowdoin and William Sever, Esqrs., with such as the Hon. House shall join, or the major part of them, be a committee to repair to the town of Sandwich, and view the premises, and report whether the cutting of a canal as aforesaid be practicable or not. And they are hereby authorized to employ any necessary surveyors and assistants for that purpose.

As a result of this resolution a committee was appointed, and apparently for the first time proceeded on scientific lines by appointing an engineer, Mr. Thomas Machin. Mr. Machin at once began a survey, but the year 1776 being an important one in the annals not only of the Colony of Massachusetts but of other colonies as well, Mr. Machin was withdrawn in June of the same year by an army officer giving more concern to making a country rather than a canal, one George Washington, who wrote to the chairman of the committee that, "The great demand we have for engineers in this department has obliged me to order Mr. Machin hither to assist in that branch of the business."

In I791, Massachusetts having now become a state, the legislature appointed a committee to again inquire into the possibility of a canal across the cape. From that time until 1824 the question 
was continually before the state legislature. In the latter year the government of the United States intervened, and by a joint resolution of both houses the President of the United States was authorized to cause the necessary surveys, plans and estimates to be made for a canal across the cape. As a result of this survey, detailed plans were finished for a canal which was to be thirty-six feet wide on the bottom, sixty feet wide at the surface of the water, with a depth of eight feet, the canal to be equipped with locks.

The eminent French engineer, Major William Tell Poussin, who visited this country in 1831 , and who, on return to France, made an extensive report on public improvements of the United States, describes, with elaborate drawings, the Cape Cod Canal as being one of the greatest pieces of construction contemplated on the American continent. From 1830 to 1860 the project languished, but in the latter year the legislature of the State of Massachusetts once more took it up, reported, and again reported in 1864. From that date until the present the question of the canal has been at intervals under discussion. The state granted a charter under which work was actually begun; funds, however, were not forthcoming in sufficient amount, the work was abandoned, and the charter allowed to lapse. In 1899 the legislature passed another charter, amended in 1900, in accordance with which plans for a canal have been prepared by the writer, submitted to the joint board of railroad and harbor and land commissioners of the State of Massachusetts, approved by them and work begun.

All the early schemes for a canal at this point contemplated locks. Brevet Major-General J. G. Foster, Lieutenant-Colonel of Engineers, U. S. Army, in I87o, was the first to call attention to the fact that, although there is a considerable difference in tidal phenomena at the two ends of the canal, nevertheless the resulting current will not be sufficient to require locks. This same view has been sustained by many eminent authorities, among them the late Colonel A. L. Rives, for many years superintendent and chief engineer of the Panama Railroad; Dr. Elmer L. Corthell, the associate with Captain Eads in the Mississippi jetties, and himself the constructor of many notable harbor developments in various parts of the world, and $\mathrm{Mr}$. Clemens Herschel. The plans that are under construction therefore contemplate a canal free from locks or dams. The law requires that the bottom width shall be not less 
than 100 feet, with passing places where the bottom width shall be twice as great, and with a minimum depth at any point at mean low water of twenty-five feet. In actual construction it is probable that the minimum width will be greatly exceeded; in fact it is most likely that the passing places, instead of being made three in number, will be connected so that the canal will have everywhere a bottom width of 150 to 200 feet, and a width at the surface of from 250 to 500 feet, depending upon the slope that the banks will take. These dimensions can be compared with a bottom width in the Suez Canal of 147 feet, in the Kaiser Wilhelm Canal at Kiel of 72 feet, and in the Manchester Canal of 120 to 200 feet; the depths of these canals vary from twenty-six to thirty feet.

From the shores of Barnstable Bay to the shores of Buzzards Bay is a distance of eight miles. The sharpest curve is projected to have a radius of 7,640 feet, so that navigation for vessels of any size within the limits of depth will be simple. At the south end Buzzards Bay is land-locked and affords an excellent harbor; at the north end the canal will flow directly into the open waters of Barnstable Bay without any natural protection. This bay is open to storms from the north and northwest. It is proposed, to provide protection against winds coming from this direction, to build a breakwater for a distance of 3,000 feet, running easterly and extending to the six-fathom curve at low water, so that vessels entering from the open bay, even in rough weather, will be able to obtain smooth conditions before entering the canal. In addition, the United States Government should construct a harbor of refuge by the building of other breakwaters, so that vessels, after having passed the canal, may lie at anchor in the waters of Barnstable Bay until such times as they are ready to continue their voyages, if delayed by stress of weather, accident or other cause. Such harbor is so obviously a part of open sea navigation that it logically should be done by the government as similar works are done along the coast, and not by a private company.

This canal is not a channel for local traffic, but is essentially a ship canal for ocean-going vessels in through service. The figures of proposed depth and width of the Cape Cod Canal show that it will be of the same general character as to size as the great ship canals of the world, and the dimensions are amply sufficient to accommodate all vessels engaged in the coastwise traffic 
at any stage of tide, and permit them to pass each other in opposite directions without hindrance. In fact, the canal will be of really greater capacity than the above figures would indicate, which are based on mean low water conditions. Since the tide rises in Buzzards Bay about five feet, the depth of water in the canal when there is high tide in Buzzards Bay will be thirty feet, a depth that will be substantially maintained at that time through the canal, as mean tide at Sandwich which occurs when there is high tide in Buzzards Bay will also give thirty feet depth at the north end. Available draft can therefore be said to vary from twenty-five feet as the minimum to thirty feet as the ordinary maximum. The latter depth would suffice to carry vessels of the battleship class, should the government ever have occasion to send such vessels through the canal.

The general trend of the Atlantic coast is northeasterly. A straight line drawn from the mouth of the Chesapeake, or the mouth of the Delaware, or from Sandy Hook, to Boston, will cut the land well to the westward of the proposed canal. The actual saving in distance will therefore be the same for any vessel trading between a Massachusetts Bay port and practically any of the ports on the Atlantic seaboard. Vessels now making this journey have two courses open. If going from New York they can pass through Long Island Sound and Vineyard Sound around the cape; or they can go by sea past Sandy Hook, and then from Montauk Point either through Vineyard Sound, as before, or to the southward of Martha's Vineyard and Nantucket Islands around the cape. Vessels from Philadelphia, Baltimore, Newport News, Norfolk, Wilmington, Charleston, Savannah, Brunswick, or any other port, can pass Montauk Point and go either through Vineyard Sound, as above, or to the southerly of the two islands.

Taking a common point of departure by the inside route through Vineyard Sound, there would be a saving in going through the canal of sixty-six miles in distance; or, by taking another common point of departure outside of Montauk Point, there would be a saving of sixty-three to seventy-one miles for vessels going through the canal instead of passing to the south of the islands, according as bad shoals are crossed or avoided. Or, if in the latter case, a vessel should wish to escape all the Nantucket shoals and make a complete circuit rather than go across, there would be 
a saving of 129 miles between New York and Boston, and I05 between Philadelphia and Boston. For points south of Philadelphia, the saving in distance would be substantially the same, although, as compared with the journey length, necessarily proportionately less. The saving in distance is not, however, the only saving that would be realized, as the worst part of the journey is the journey around the cape, whether it lies across the shoals or goes around them.

Fogs, storms, and adverse currents frequently keep vessels storm-bound either at Provincetown or in Vineyard Sound for days at a time, so that no certain time of arrival can be predicated even for vessels in tow, still less for vessels under sail, while the terrible list of wrecks on the shores of the cape attest the foolhardiness of attempting to make the journey in bad weather. During the year 1905, the last for which statistics are available, fourteen vessels were lost on the shoals and the short stretch of thirty-five miles of Cape Cod coast. The tonnage of these wrecks composed 24. I per cent, or say one-quarter, of the total tonnage of wrecks reported on the whole coast line of Maine, New Hampshire, Massachusetts, Rhode Island, Connecticut and Long Island. So measurable is the danger of Cape Cod transit, as compared with the quiet navigation of Buzzards Bay and the canal, that inquiries addressed to the marine underwriters in New York elicited the response that insurance rates on the cargoes of sailing vesels and barges would be reduced from to to 25 per cent to vessels using the canal.

The traffic that would seek the canal route is of three classes:

First. Passenger steamers between New York and Boston. This business is now handled in two ways: by vessels running to Fall River, Providence, New Bedford, or other sound ports, and thence by rail to Boston, or by vessels going around the cape. The first method requires but one night for the journey, but it involves a transshipment of passengers and freight inconvenient to the former and expensive for the latter. The second method requires usually eighteen to twenty hours, or say a night and the forenoon of the following day, unless further delayed by thick weather. The canal will permit the journey to be completed in thirteen to fourteen hours, or comfortably between evening and early morning. To show the extent of this traffic, there are running regularly every night between New England ports, exclusive of any north of Boston, twenty-four large steamers both ways, of which sixteen carry 
passengers. During the summer not only is the total increased, but also the percentage carrying passengers. Of the twenty-four, the New England Steamship Company controls sixteen. All these steamers pass out through Long Island Sound, and by far the greater portion of the passengers and freight would be more expeditiously, economically and comfortably handled through the canal.

Second. Steamers carrying chiefly freight, but also some passengers, between Boston and ports south of New York. Lines are regularly established from Boston to Philadelphia, Baltimore, Norfolk, Charleston, Savannah and Jacksonville, with twenty sailings weekly both ways, offering an annual freight capacity of more than $2,000,000$ tons. In additon there is a large volume of freight traffic, chiefly fruit, from the West Indies and Central America, steamers from such ports entering at Boston Custom House to the extent of over 200 annually. All this traffic could save by the canal, and much of it will use it.

Third. Freight traffic of raw materials transported in sailing vessels or barges. This traffic would furnish the major volume of the canal business, and it consists chiefly in coal, southern lumber for New England, Maine lumber, such as spruce for points south of the cape, stone from Massachusetts and Maine, ice south-bound, cement, brick and lime north-bound, oil and oil products, cotton reshipped at New York, and other bulky commodities. Such articles must be transported cheaply. The New England railways leading from New York are now so congested with passenger traffic and the carrying of high classified freights that such articles as those stated above cannot be given the low rates that their value demands-such traffic must go by sea.

In point of tonnage the biggest item in the above list is coal. During the year ended June 30 , 1907, it is estimated that the coal shipments to Massachusetts Bay ports, of which Boston and Portland are the chief, amounted to no less than $12,000,000$ tons which were shipped from New York, Philadelphia, Baltimore and Norfolk. Exclusive of the freight carried in the regular coastwise steamers, it is estimated that the other commodities aggregated during the year some $5,000,000$ tons, making a gross total of about $18,000,000$ tons.

From these statistics, and the diversified points of origin of traffic, it will be seen that this canal is of national importance. Although nominally the bulk of the cargoes that will use it north- 
bound start from New York, that port is not the originating point. The cargoes represent the produce of the many states seeking their market through a convenient channel-coal from Pennsylvania and West Virginia, tobacco from Virginia and the Carolinas, timber from Georgia, cotton from the whole of the great South. It is an enterprise in which every state on the Atlantic seaboard, from Maine to Florida and Texas, is interested.

If the volume of traffic already in existence is so great, and the saving in distance, delay and danger of such importance, the question naturally arises why, after 300 years of agitation, the canal was not built before. The answer to this very natural question will be found in the change that has been taking place in water transportation, a change which has made it possible for the State of New York to throw away its enormous investment in the existing canal system of the state and build an entirely new system from Lakes Erie, Ontario and Champlain to Albany, at a cost of over \$100,ooo,o0o.

As long as the coastwise traffic was controlled by schooners, with a recognized unknown length of journey and an amount of delay impossible to forecast, the value of the distance and time saved was not of so much importance as to overcome the expense to a sailing vessel in traversing the more or less narrow waters of Buzzards Bay and being towed through the canal. Steam, however, within the last few years has been making the same inroads into the methods of coastwise traffic that it has already made in ocean traffic, so that the schooner is following in the footsteps of the picturesque clipper ship, and is giving way to the tug and tramp steamer.

As soon as a vessel owner adopts as a motive power an agent that will enable him to send his vessels on a schedule he at once begins to take account of delays, and places a money value against the time lost. This method of reasoning-and it is sound-warrants the expenditure of large sums in the improvement of waterways, such as the Cape Cod Canal, that would not have been, and were not, justifiable one or two decades since.

To-day the greater part of the coal traffic between New England, New York, Philadelphia and Norfolk is handled in barges, usually two or three in number, behind an ocean-going tug. To show the extent to which the new methods of transportation 
are superseding the old, the statistics compiled by the chamber of commerce for the port of Boston each year are at hand. In 1902 there arrived in Boston from domestic ports south of Cape Cod I,033 steamers, 1,209 sailing vesels, 909 tugs and 1,879 barges; total, 5,030. In I906, four years later, there were I,I48 steamers, 900 sailing vessels, I,I 66 tugs, and 2,458 barges; total, 5,672 . The aggregate vessel tonnage of the former year was a little over 5,000,000 tons, and of the latter nearly 7,000,000 tons.

The thing that strikes one in these statistics is the small increas. in vessel number and yet the large increase in vessel tonnage, indicating an increase in average size of unit. While the total number of steamers remains substantially the same, sailing vessels have decreased 25 per cent in number and the barges have increased more than 33 per cent in number.

In 1902, of the total entrances at Boston, steamers comprised 20.5 per cent, tugs 18 per cent, sailing vessels 24 per cent and barges 37.5 per cent. The same division in 1906 was : steamers 20.3 per cent, tugs 20.6 per cent, sailing vessels 15.8 per cent, and barges 43.3 per cent. Or, taking the United States Government figures for 1905 and comparing them as a matter of convenience with the census returns for the year 1899 , of the total tonnage carried to Boston 53.9 per cent went in steamers in 1899 , and exactly the same in 1905; but while barges carried but 21.1 per cent in 1899 , they carried $3 \mathrm{I} .3$ per cent in 1905 , and the sailing vessel tonnage, which had accounted for 25 per cent of the whole in the first year, had fallen to 14.8 per cent in the second.

This same general change in traffic conditions will apply equally to all waterways that are to be hereafter constructed, and any waterway that is either to be constructed anew or to be made by the improvement of existing conditions, must be undertaken with the view of its exploitation by vessels whose power will be for the most part something other than sails. With the Cape Cod Canal established, the great source not only of danger but of delay will have been removed, and the towing companies, whether private or part of the various coal companies' equipment, can estimate with reasonable certainty upon the time of departure and arrival of their tugs, in fact with a much greater certainty than for similar shipments by rail.

Its national rather than local character is to be impressed on 
the attention of this convention, as this canal will do more than make a water route from New York to Boston. It will at once, by means of the Raritan, Delaware and Chesapeake, and other canals, complete an inside route safe at all seasons for all boats from North Carolina to Maine, and that without a single dollar more to be invested by the nation or any state. From that point the labors of this convention can be exerted to deepen, widen and develop the existing links and construct the others that are now lacking, so that this inside route may be continuous and of sufficient size for modern requirements. To this end not only must canals be built and small rivers enlarged, but the attention of those in authority must be directed to the further increasing of the capacity of the limiting conditions of some of the main arteries. The port of New York is the country's largest gateway. The general government has been at work for years, and has at last almost completed a new deep channel to sea. That channel is, however, for foreign commerce. The harbor has another entrance from the sound through the East River; this is the channel for internal commerce. It is the channel on which three states-New York, Connecticut and New Jersey-look directly, and it is the one used chiefly by the domestic ocean commerce of the Atlantic States. Although much improved over conditions existing twenty years ago, it is still much restricted by islands, reefs and narrow channels. If any great inland route is to be established it becomes the throat where all traffic will be congested; it is the one place which all are interested in having developed; it is one of the improvements to be most urged by this convention upon the national authorities. 